\title{
The Role of the International Monetary Fund After the 2008 Crisis
}

\author{
Marco Mele $^{1} \&$ Floriana Nicolai ${ }^{2}$ \\ ${ }^{1}$ University of Teramo, Italy \\ ${ }^{2}$ Unint University, Italy \\ Correspondence: Marco Mele, University of Teramo, Italy.
}

Received: June 4, 2019

Accepted: June 22, 2019

Online Published: June 24, 2019

doi:10.5430/rwe.v10n1p60

URL: https://doi.org/10.5430/rwe.v10n1p60

\begin{abstract}
The purpose of this paper is to analyze the changes in the functions of the International Monetary Fund after the 2008 financial crisis. Following an extensive introduction concerning the subject of the study and which covers part of the economic literature, the focus was on governance reform and surveillance in the foreign exchange market. Finally, the empirical analysis was carried out concerning the manipulation of exchange rates in a period ranging from 2008-2016 and 15 countries (Taiwan, South Korea, Israel, China, Thailand, Macao, Switzerland, Hong Kong, Singapore, Norway, Qatar, United Arab Emirates, Kuwait, Trinidad and Tobago and Saudi Arabia) that in the period considered massively intervened in the foreign exchange market, keeping their respective currencies undervalued and acquiring an unfair competitive advantage to the detriment of partner economies. The results would tend to confirm that the manipulation of the exchange rate is a persistent and lasting element of the currency policies of the new millennium, highlighting an active insufficiency of the IMF's action in the exercise of the oversight function on the currency policies of the Members.
\end{abstract}

Keywords: FMI, NOFs, NOAs, exchange rate, governance reform

JEL classifications: E42, F02, F42, G20.

\section{Introduction}

The IMF's activity in the new millennium has been profoundly influenced by the explosion of the financial crisis that erupted in the US in 2008 and then spread to the rest of the world. As has been pointed out by extensive literature at the root of the crisis, various factors were posed. In particular, it was rooted in the housing market bubble, fueled by prolonged house price increases and favored by the spread of financial engineering operations. The bubble has been inflated by the accommodating monetary policy undertaken by the Federal Reserve of Alan Greenspan since 2001 (Taylor, 2007; Catte et al., 2010) and the deregulation of financial markets.

In an attempt to contain the recessionary effects of the end of the new economy boom, Greenspan has kept nominal and real interest rates "too low and too long" (Taylor, 2009). The result was a money glut that stimulated the recourse to debt and the increase in consumption, which was associated with a further contraction in the savings of US households and an influx of low-cost foreign capital. However, the belief that the US financial system could have endured massive and uninterrupted capital inflows without any problems probably created the basis for the global financial crisis as the high returns offered in the financial markets were, in reality, the result of an amplification caused by capital inflows (Reinhart, Rogoff, 2009).

The deregulation of financial markets has allowed the growing use of risk hedging instruments which, in turn, led to the expansion of mortgage loans to non-primary customers, or to buyers with insufficient income to guarantee their solvency. The fragility of the system that had been created, based on risky and opaque securities, was highlighted by the credit crunch made in 2004. In fact, the increase in interest rates, making it challenging to honor mortgage debts, gave rise to a crisis of insolvency and the explosion of the housing bubble.

In this scenario, criticisms of the Fund's actions have arisen which have been oriented where its failure has appeared, namely in the inability to identify, through multilateral and bilateral surveillance, the factors which, accumulating and interacting with each other, have led to the crisis. In particular, its responsibilities for not anticipating the crisis, its timing or its size, warning Members of the related dangers, and failing to identify the risks and vulnerabilities that were accumulating, especially in financial centers systemically important, they are not negligible. For example, in 
the World Economic Outlook published in April 2007, the IMF, observing that the fluctuations on every kind of risky assets had been reduced, came to the conclusion that for the global economy the risks had become extremely low, that there were they were great concerns and a continuation of the growth phase observed during the "great moderation" period was indicated as the most probable scenario (WEO, 2007). Furthermore, the IMF often praised the United States and the United Kingdom for their regulation and supervision at "light-touch", which had allowed rapid financial innovation. It publicly praised the financial model of the two countries and, in particular, the derivatives system, securitization, subprime mortgages, and so on, and also recommended other countries to follow the example of the US and the UK to benefit from the advantages offered by financial innovation. In this way, the Fund has mostly underestimated the imbalances that were accumulating in the US financial market.

The IEO carried out an analysis aimed at evaluating the performance of the IMF in the period from 2004 to 2007, from which it emerged that the bankruptcy of the institution in the years preceding the economic and financial crisis was attributable to three main factors: a) the analytical weakness; b) organizational impediments; c) political-institutional problems (IEO, 2011).

a) The analytical weakness refers to an aspect of a purely psychological nature and one of an intellectual view. The element of the mental matrix is the so-called groupthink or group thought, that is the tendency of homogeneous and cohesive groups to consider the questions only within a well-defined conceptual paradigm without questioning the founding premises (Janis, 1982). To minimize conflicts and reach consensus, the dialectical process is avoided and, therefore, in-depth analysis and critical evaluation of the various positions, thus preventing the formation of opposing opinions and, instead, allowing the points of view to remain within consensus thinking (Finnemore, Evans, 2001). It is through this dynamic that, according to the IEO, the behavior of the IMF staff can be explained - defined as a cohesive group of macroeconomists convinced that "market discipline and self-regulation would be sufficient for serious problems in financial institutions" (IEO, 2011, p.17) - to avoid proposing considerations that could be perceived as heterodox, for fear of receiving judgments from other members of the group. Furthermore, in this context it would have operated what in social psychology is defined as "intellectual capture" or the tendency of people to notice only information consistent with their expectations, ignoring those that are not (Bazerman, Moore, 2009). This would explain the attention paid by the staff to what was the first concern of the IMF, relating to global imbalances and a potential sharp dollar depreciation, ignoring other risks. The intellectual aspect identifies the choice of analytical approaches and knowledge gaps as one of the sources of the IMF's failure to determine the threats and vulnerabilities of the economic system. The report showed that the research carried out by the IMF economists did not provide an analysis of the link between the macroeconomic and financial sectors. In particular, the Fund economists tended to make extensive use of mathematical models that proved inadequate to analyze macro-financial relationships.

b) The organizational impediments highlight some weaknesses in the structure of the institution and, in particular, its hierarchical organizational structure and well-defined boundaries. They are due to the so-called "silo behavior" which refers to the fact that the staff tended not to share information or ask suggestions to other units or other departments. This would have made "challenging to integrate multilateral with bilateral surveillance, to link macroeconomic and financial developments, and to draw lessons from cross-country experience. Discussion of risks and vulnerabilities that led to the crisis never found its way into the bilateral surveillance of the most essential systemic financial centers. Because of this deficiency, the essential coordination for the risk assessment between bilateral and multilateral surveillance would have been lacking.

c) The political and institutional problems derive from the voting mechanism of the Institution, determined, as observed by other authors, by the monetary contributions of the Members who establish their weight in the IMF. This system has proved to be doubly advantageous for the advanced countries as it has not only allowed these economies to have higher weight compared to those emerging in the decision-making process of the Fund, ie, in one of the most influential international organizations in choosing the direction of economic policies. On a global level, but it has also allowed it to be subjected to milder surveillance than that involving the emerging countries. This last aspect would find an explanation in what the IOE has defined as a problem of disincentives. From this fragment of the IEO analysis, it is clear, therefore, that many members of the IMF staff felt the presence of strong disincentives to reveal what emerged from the research results and, consequently, they would not have supported visions contrary to those of the authorities of the most powerful countries within the Fund. In this way, a sort of self-censorship mechanism would have been created since "many staff members believed that there were limits to how to determine the policies of the largest shareholders - that they cannot speak truth to you since you re-owned by these governments. The weakness of the Fund's action limits before the explosion of the financial crisis has favored a reform process that has involved three areas: governance, the supervisory function, and financial assistance. 
Concerning governance, after a long delay due to the failure to ratify by the United States Congress, a first reform of the government structure came into force to recognize developing countries and to emerging economies a higher weight in the institution's decision-making process. It provided for a revision of the formula used for the calculation of the quotas and redistribution of the same, with an increase in favor of the under-represented countries to their respective GDP.

Compared to the surveillance, the Fund has undertaken a series of initiatives aimed at strengthening the reference framework and the tools of its supervisory activity, filling some gaps highlighted by the crisis and revealed, as mentioned above, by the IEO. They culminated in the adoption of the decision on integrated surveillance (Integrated Surveillance Decision - ISD) establishing a new legal framework for the performance of the supervisory function that allows the IMF to evaluate all relevant policies for internal and external stability of the Members and to take into account the inward spillovers and outward spillovers and the interactions between the policies of the different countries. Equally, the adoption of the Financial Supervision Strategy was an important step to improve risk identification and policy analysis in the financial sector. Regarding financial assistance, the IMF reacted promptly to the increased request for financial aid by increasing the size of the credit lines, developing a more flexible approach to conditionality, approving new precautionary branches and disposing of the little-used ones (Moreno, 2013) and diversifying the effort geographically.

\section{The Governance Reform}

The reform provided for a revision of the formula used for the calculation of the quotas and redistribution of the same, with an increase in favor of the under-represented countries concerning their respective GDP. In particular, the formula adopted at the end of the Bretton Woods conference had been developed by the US to crystallize the balance of powers that had already been created before the Second World War, and the results of its application were codified in Annex A of the IMF Statute. It gave higher weight to the national income; consequently, the countries with the most critical economic dimensions had the most top shares. In the formulas developed in the following decades an attempt was made to define the value of the States' share based on the economic dimension, the degree of openness to international trade and foreign exchange reserves, so as to ensure a favorable position also for those countries which, although of limited size, they had a high degree of economic integration.

In 2008 the mathematical formula for calculating the quota was again modified to "provide simpler and more transparent means of capturing members' relative positions in the global economy" (IMF, 2008, p. 9). The current formula for calculating quotas is based on a weighted average of GDP (50\%), degree of openness (30\%), fluctuations in international payments and net capital flows from abroad (15\%), and official reserves held (5\%).

As can be seen from Table 1, the quota structure has changed radically compared to that of 1947. In that year the US and the United Kingdom, the countries that had led the Bretton Woods negotiations, held shares of 35, 62 and to $16.84 \%$, respectively. The other two major shareholders were, at a considerable distance, China $(7.12 \%)$ and France $(6.80 \%)$. Today the US share is just under half that of 1947, but still sufficient to give the country "a veto power" over some decisions. The weight of the United Kingdom, on the contrary, has been dramatically reduced and is equal to that of France (4.24\%). The changes in the structure of the shares reflect the rise of Germany and Japan to the rank of major economic powers. The two countries, which became members of the IMF in 1952, have significant shares, which however remain much lower than those of the USA. Changes in quotas have also occurred for emerging countries. China and India had larger shares in 1947 than current ones but grew compared to the 2006 figure. Saudi Arabia, Mexico, and the Russian Federation have gained more prominence.

Table 1. IMF members' quotas: 1946, 2006, 2016

\begin{tabular}{lccc}
\hline Member Countries & \multicolumn{3}{c}{ Shares } \\
\hline & 1947 & 2006 & 2016 \\
\hline USA & 35,62 & 17,07 & 17,46 \\
\hline Japan & - & 6,12 & 6,48 \\
\hline Germany & - & 5,98 & 5,60 \\
\hline France & 6,80 & 4,93 & 4,24 \\
\hline UK & 16,84 & 4,93 & 4,24 \\
\hline Italy & 2,33 & 3,24 & 3,17 \\
\hline
\end{tabular}




\begin{tabular}{lccc}
\hline Canada & 3,89 & 2,92 & 2,32 \\
\hline Netherlands & 3,56 & 2,37 & 1,84 \\
\hline Belgium & 2,91 & 2,11 & 1,35 \\
\hline Saudi Arabia & - & 3,21 & 2,10 \\
\hline China & 7,12 & 3,71 & 6,41 \\
\hline India & 5,18 & 1,91 & 2,76 \\
\hline Russia & - & 2,73 & 2,71 \\
\hline Brazil & 1,94 & 1,39 & 2,32 \\
\hline Mexico & 1,17 & 1,44 & 1,88 \\
\hline
\end{tabular}

Source: 1947, IMF, Annual Report, 1947; 2006,

https://www.imf.org/external/pp/longres.aspx?id=3885; 2016

http://www.imf.org/external/np/sec/memdir/members.aspx

Furthermore, the reform led to a $300 \%$ increase in the total essential votes, with the result that each Member was given no more than 250 , but 750 necessary votes, to which are added those proportional to the subscribed capital shares. An automatic rebalancing mechanism has also been introduced by virtue of which the percentage of essential votes will remain constant concerning the total voting rights of the Members. Furthermore, it has launched a doubling of States Parties quotas, through a generalized increase of $60 \%$ for all Members and a remaining $40 \%$ of ad hoc increases for those under-represented.

Therefore, the objective of guaranteeing a coherent representation with the equilibrium of the global economic system has been ensured by a shift of $6 \%$ of the quotas from the over-represented countries to the under-represented ones. This reform, therefore, recognizing the new geopolitical balances and the growing dynamism of emerging economies represents a first attempt to reinforce the credibility, legitimacy, and effectiveness of the governance of the IMF.

\section{Currency Market Surveillance}

The concurrence of different circumstances - the financial crisis exploded in the United States and the prolongation of its effects, that of sovereign debts in the euro area, the slowdown in growth rates of the BRICS countries, the introduction of an overabundant liquidity especially in the United States and the Eurozone, which led to a reduction in interest rates on financial assets in dollars and euros - caused growing volatility on the currency markets.

In a climate of uncertainty and strong tensions on the interbank markets in the leading advanced economies, the central banks of the countries involved have resorted to unconventional monetary policies (Unconventional Monetary Policies, UMPs) which, according to some, would have had the effect of altering international competitiveness.

As is known, since 2008 the central banks of the United States, Japan, the United Kingdom and the euro area (the so-called Systemic Four, S4) have started programs to increase the monetary base without precedent. These interventions, even if implemented for internal stabilization purposes, had the effect of increasing the monetary circulation in a situation in which interest rates were already at the limit of the lower zero bound, generating, in a context of flexible exchange rates a depreciation of the respective currencies.

In the context of a general slowdown in the global economy, the central banks of the S4s were accused of having conducted "currency wars", that is to say of having deliberately adopted accommodative monetary policy measures in an "unconventional" way, not caring about the effects that they would have had on exchange rates, improperly altering the competitiveness of national productions and damaging that of their commercial partners.

In the absence of a consensus on the effects of UMPs and of real international cooperation, these policies have been interpreted as motivated by the pursuit of national interest, arousing a chain of actions and reactions. In fact, from the analysis of the graph Figure 1, we note how the currencies of the countries that have adopted UMPs since 2009 have started to record changes in their exchange rates. In particular, as far as the US is concerned, the depreciation of the dollar coincided with the launch, at the end of 2008, of the first quantitative easing maneuver (QE1), strengthening with the launch of QE2 (November 2010). However, starting from the second half of 2011 the worsening of the growth prospects in the advanced countries and the uncertainty about the evolution of public finances in some 
Eurozone countries triggered a phase of marked instability in financial markets. Despite the adoption of QE3 (September 2012), the American currency has begun to record a growing trend that has been mirrored in contrast with the decreasing trend of the single European currency on which the effects of the sovereign debt crisis weighed. Starting from the second half of 2014, the dollar returned to appreciate also due to the different monetary policy orientations in the advanced economies with the United States that reversed its trend - starting the so-called tapering, or rather the slow reduction of the injection plan liquidity in the financial markets - while the central banks of the Euro Area and Japan have continued to adopt policies of the opposite sign.

The analysis of the single currency shows how the changes in the euro in the foreign exchange market were first influenced by the excessive volatility recorded during the sovereign debt crisis and then by the adoption of real operations of quantitative easing by the ECB. In particular, in the period following the 2008 economic-financial crisis, two decreasing trends were recorded in the real exchange rate trend of the single currency (Figure 1). The first occurred in 2010 due to the climate of distrust due to the economic and political instability of the Eurozone deriving from the sovereign debt crisis and from the inability of European governance to give useful and quick answers to the spread of the crisis. The second is, instead, attributable to the quantitative easing measures conducted by the ECB starting from 2015.

The Japanese currency has shown a strong appreciation phase since 2008, the reasons for which can be traced on the one hand to the fact that it played the role of a safe-haven asset and on the other to the acceleration of the closure of carry trade positions following the reduction of the interest differential on funds in other major currencies and the marked increase in market volatility Bank of Italy, 2008). Starting in 2013, this trend was abruptly reversed when the Bank of Japan also inaugurated the Quantitative and Qualitative Easing (QQE), an inflationary policy to combat the problem of deflation (Bank of Italy, 2013). Although it was part of a broad strategy of economic and financial policy (known as Abenomics), it led to a sharp devaluation of the yen and many Asian countries accused Japan of conducting a "clandestine currency war" pushing them to adopt, for compensation, other forms of monetary expansion (De Arcangelis, 2013; Marzovilla and Romagnoli, 2016).

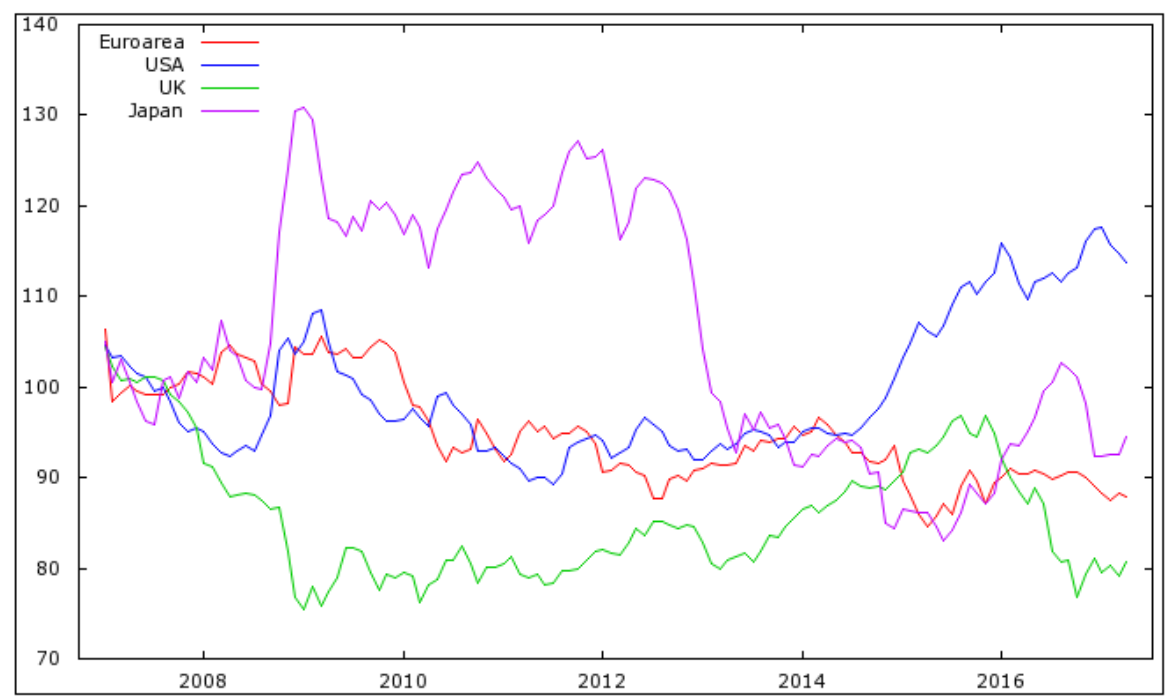

Figure 1. Real effective exchange rate, 2007 - 2017: Euroarea, United States, United Kingdom, Japan index $(2007=100)$

Source: our eleboration. BIS, 2017

Therefore, these interventions, even if implemented for internal stabilization purposes, have been heavily criticized by the emerging countries, and by the BRICS in particular, which have given them the primary responsibility for the appreciation of their currencies.

Figure 2 shows the real effective exchange rates of the BRICS countries starting from 2007 and shows that in 2009-2011 there was an appreciation in real terms with a very similar dynamic between the different countries. In 
fact, the attenuation of aversion to global risk and the low-interest rates in advanced economies have favored the rapid recovery of capital inflows towards these economies, determining the appreciation of their currencies. These "hot money" waves led to an increase in the prices of financial assets and prompted the authorities to take extraordinary measures to control capital movements also to avoid further currency revaluations. However, starting in 2012 and up until the US tapering, the appreciation stopped, and there was a divergence in the trends of the various currencies, with some appreciating (renminbi and ruble) and others depreciating (real, rupiah, rand). In particular, the reversal of the US monetary policy trend, resulting in interest rate increases, favored capital outflows from emerging countries, increasing the burden of their foreign indebtedness and volatility in the foreign exchange market, fueled by also from the collapse in the price of commodities. In this context, the currencies of commodity-exporting countries (Brazil, Russia, and South Africa) have sharply depreciated in real terms before returning to appreciate in 2016, benefiting from the recovery in prices.

Instead, the RMB followed a different trend deriving from the process of internationalization administered by China since 2008. This led to a gradual appreciation of the Chinese currency continued until 2014. Subsequently, the depreciations of 2015 and those of 2016, connected to the reversal of capital flows, they brought it back to RMB 6.92 per dollar (Pacific Exchange Rate). In order to reassure the markets, the Chinese authorities intervened in the foreign exchange market spending about 320 billion dollars of official reserves in order to support the currency (IMF Art. IV Consultation, 2017).

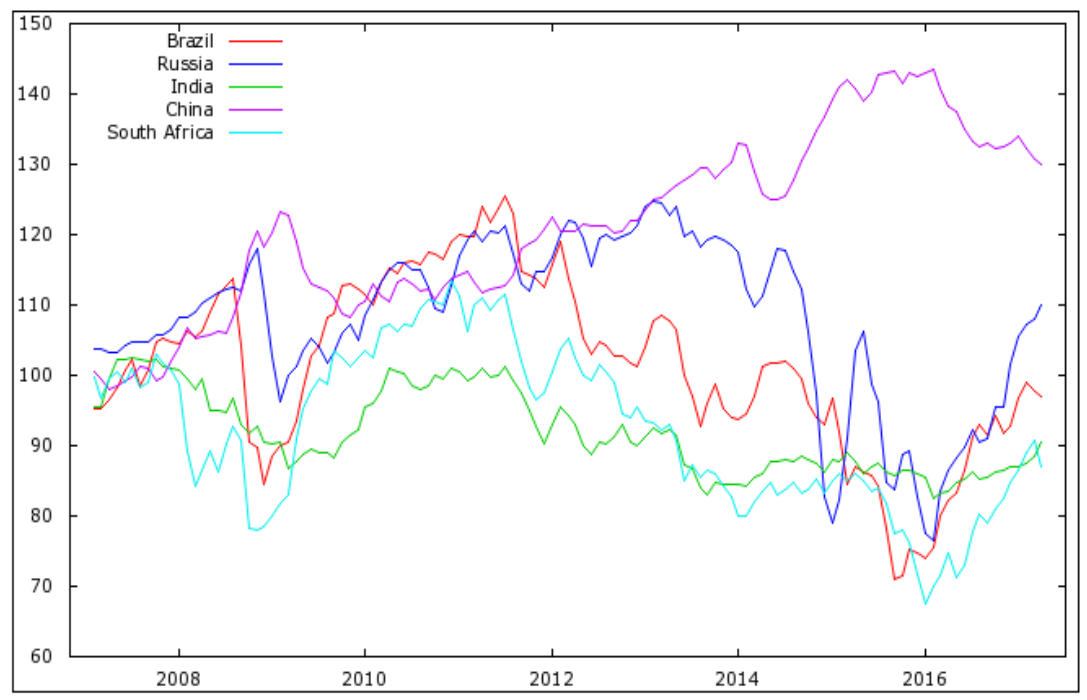

Figure 2. Real effective exchange rate, 2007 - 2017: Brazil, Russia, India, China, South Africa

index $(2007=100)$

Source: our elaboration. BIS, 2017

In this context of significant instability, the Fund through the Spillover Reports of 2011 and 2012 has identified the side effects of unconventional monetary policies on financial markets and the volatility of exchange rates in the so-called "non-UMP countries". In particular, it highlighted the growing financial instability fueled by the expansion of credit (GFSR, April 2013), the risks deriving from destabilizing capital movements driven by the interest rate differential (IMF, 2013a), as well as those deriving from the trend reversal in US monetary policy (IMF, 2013b).

The Fund, therefore, operated in an area where the difficult problem of balancing the needs of countries with different preferences, interests and difficulties was posed. In fact, on the one hand, emerging countries have complained that they have been "net importers of external influences" (IMF, 2011, p. 7) that have negatively affected internal dynamics, accusing advanced countries, as mentioned above to have conducted currency wars with unconventional weapons, manipulating their currencies. On the other hand, developed countries have claimed to have adopted expansive monetary policies for internal purposes, to reinvigorate national economies, and not to achieve unfair advantages. In this perspective of international monetary disorder, it is advisable to assess whether the 
write-downs occurring since 2008 can adequately be considered as exchange rate manipulations adopted to secure unfair competitive advantages vis-à-vis other states.

\section{Empirical Analysis: Estimate on the Manipulation of the Exchange Rate}

The economic literature has developed some criteria to assess whether there is a manipulation of the exchange rate. In particular, this exists where countries register simultaneously: a current account surplus greater than 3\% of GDP; net official flows (NOFs) greater than 2\% of GDP; a level of reserves, expressed through net official assets (NOAs), greater than $30 \%$ of short-term external debt, $15 \%$ of financial liabilities, $10 \%$ of M2 monetary aggregate and $10 \%$ of exports to countries with fixed exchange rates and more than $30 \%$ of short-term foreign debt, $10 \%$ of financial liabilities, $5 \%$ of the M2 monetary aggregate and $5 \%$ of exports in economies with fluctuating rates.

Based on the above criteria, we decided to identify specific countries, out of a total of 184 economies, which have manipulated the exchange rate in the period between 2008 and 2016.

As a unit of measure for interventions in the foreign exchange market, we use the NOFs defined as the sum of official reserves (consisting of foreign currencies, the reserve position at the IMF, special drawing rights and monetary gold) and the other reserve assets (divided into securities, cash and deposits, and other receivables) net of financial investments, other investments and derivatives held by central banks and other public administrations. The data for official reserves and other reserve assets are taken from the International Reserve and Foreign Currency Liquidity of the IMF under the items "Official Reserve Assets and Other Foreign Currency Assets", those on financial investments, other investments and derivatives from the account Financial Statement of the IMF Balance of Payments (BOP) database.

To calculate the level of reserves available to the monetary authorities, the NOAs were used which, as already mentioned, make it possible to integrate the concept of international reserves with that of foreign currency liquidity (IMF, 2001, International Reserve and Foreign Currency Liquidity: Guidelines for a Data Template). They are equal to the sum of official reserves and other reserve assets net of predetermined short-term outlays and potential future outlays on foreign currency resources. The data for the predetermined and potential short-term future outflows were derived from the International Reserve and Foreign Currency Liquidity under the items "Predetermined Short Period Net Drains of Foreign Currency Assets" and "Contingent Short - Period Net Drains of Foreign Currency Assets ". For the missing values, we used the Bergsten and Gagnon database (2017). Established, through the NOAs, the actual level of reserves available to the monetary authorities, it must be compared with the optimal or desirable one in order to understand if the actual level is above, below or in line with the optimal one. The optimal level of reserves, as mentioned above, in economies with fixed rates is equal to:

- $30 \%$ of short-term foreign debt $+15 \%$ of financial liabilities $+10 \%$ of M 2 monetary aggregate $+10 \%$ of exports; and in countries with flexible exchange rates is:

- $30 \%$ of short-term foreign debt $+10 \%$ of financial liabilities $+5 \%$ of M 2 monetary aggregate $+5 \%$ of exports.

Data on short-term foreign debt, those on financial liabilities (calculated as the sum of the items "Other investment liabilities" and "Portfolio investment liabilities") and on the M2 aggregate were obtained from the Assessing Reserve Adequacy (ARA) database of IMF, while those on exports from the World Economic Outlook (WEO, April 2017). Information on the exchange rate regime adopted by the various economies between 2000 and 2008 was taken from the Annual Reports on Exchange Arrangements and Exchange Restrictions.

By applying the aforementioned criteria and processing the data using Stata15 software, we have identified fifteen countries (Taiwan, South Korea, Israel, China, Thailand, Macao, Switzerland, Hong Kong, Singapore, Norway, Qatar, United Arab Emirates, Kuwait, Trinidad and Tobago and Saudi Arabia) which intervened massively in the foreign exchange market between 2008 and 2016.

In particular, as can be seen from Table 2, all countries, except for Korea, Thailand, Israel, and Trinidad and Tobago have registered NOFs far exceeding $2 \%$ of GDP. The economies that have intervened most in the foreign exchange market are, again, the countries belonging to the group of manufacturing exporters that registered NOFs amounting to 2.153 trillion dollars, followed by exporters of natural resources with 1.919 trillion dollars and by financial centers with equal interventions at 1.189 trillion dollars. China qualifies, in absolute terms, as the principal architect of excessive manipulation of the foreign currency market (\$1,796 trillion).

The current account surplus was also significantly higher than 3\% of GDP in almost all the economies included in the table. In fact, only Israel and China have shown value in line with the 3\% threshold. As for the optimality of the reserves, in all countries, the actual level was higher than the desired one. Considering China, for example, the 
average NOAs - and therefore the actual level of reserves - in the period in question amounted to $\$ 2,941$ trillion, whereas \$ 1,191 trillion would have been sufficient to meet precautionary or precautionary needs. Similar considerations apply to all other countries identified by the analysis.

Table 2. Currency manipulators, 2008-2016

\begin{tabular}{|c|c|c|c|c|c|c|c|}
\hline \multirow[t]{2}{*}{ Economy } & \multirow{2}{*}{$\begin{array}{l}\text { Episodes of } \\
\text { manipulation }\end{array}$} & \multicolumn{2}{|c|}{$\begin{array}{c}\text { Average net } \\
\text { official assets }\end{array}$} & \multicolumn{2}{|c|}{$\begin{array}{c}\text { Net } \\
\text { official flows }\end{array}$} & \multirow{2}{*}{$\begin{array}{l}\text { Avarage } \\
\text { current } \\
\text { account as } \\
\text { percent of } \\
\text { GDP }\end{array}$} & \multirow{2}{*}{$\begin{array}{c}\text { Reserve Adequacy } \\
\begin{array}{c}\text { Optimal level (Average, } \\
\text { billions of dollars) }\end{array}\end{array}$} \\
\hline & & $\begin{array}{c}\text { Billions } \\
\text { of } \\
\text { dollars }\end{array}$ & $\begin{array}{c}\text { Percent } \\
\text { of } \\
\text { GDP }\end{array}$ & $\begin{array}{l}\text { Billions of } \\
\text { dollars }\end{array}$ & $\begin{array}{l}\text { Percent } \\
\text { of GDP }\end{array}$ & & \\
\hline \multicolumn{8}{|c|}{ Manufacturing exportes } \\
\hline Taiwan & 5 & 350 & 65 & 170 & 4 & 11 & 87 \\
\hline Korea & 4 & 322 & 23 & 19 & 2 & 5 & 143 \\
\hline Israel & 3 & 66 & 22 & 70 & 3 & 3 & 20 \\
\hline China & 3 & 2.941 & 34 & 1.796 & 4 & 3 & 1.911 \\
\hline Thailand & 1 & 158 & 39 & 98 & 2 & 4 & 55 \\
\hline
\end{tabular}

Financial Centers

\begin{tabular}{lccccccc}
\hline Macao & 8 & 21 & 52 & 54 & 14 & 32 & 7 \\
\hline Switzerland & 6 & 356 & 45 & 655 & 9 & 9 & 240 \\
\hline Hong Kong & 5 & 260 & 87 & 234 & 9 & 5 & 222 \\
\hline Singapore & 5 & 478 & 162 & 246 & 10 & 19 & \\
\hline
\end{tabular}

Resource exporters

\begin{tabular}{|c|c|c|c|c|c|c|c|}
\hline Norway & 8 & 643 & 120 & 460 & 10 & 11 & 65 \\
\hline Qatar & 8 & 173 & 103 & 119 & 8 & 17 & 11 \\
\hline $\begin{array}{l}\text { United Arab } \\
\text { Emirates }\end{array}$ & 8 & 798 & 228 & 704 & 19 & 8 & 27 \\
\hline Kuwait & 7 & 257 & 191 & 318 & 21 & 28 & 25 \\
\hline $\begin{array}{l}\text { Trinidad and } \\
\text { Tobago }\end{array}$ & 6 & 14 & 58 & 6 & 3 & 6 & 3 \\
\hline Saudi Arabia & 5 & 508 & 71 & 312 & 5 & 10 & 74 \\
\hline
\end{tabular}

Consequently, these economies have achieved unfair competitive advantages by pursuing beggar-thy-neighbor policies.

The results of our study would, therefore, tend to confirm that the manipulation of the exchange rate is a persistent and lasting element of the currency policies of the new millennium, demonstrating how they have contributed to delaying or preventing the adjustment of the balance of payments and to revive the problem of global imbalances. 
The considerations conducted so far denote, still, a sharp insufficiency of the IMF's action in the exercise of the oversight function on the currency policies of the Members attributable to various reasons.

First of all, it should be remembered that pursuant to the Articles of Association and the Integrated Surveillance Decision a manipulation of the exchange rate exists where it is possible to prove beyond reasonable doubt that the Member thanks to it has obtained an unfair competitive advantage and that a concrete situation of external instability is directly determined by the currency policies adopted by the State concerned. In light of these observations, we understand the difficulties of identifying those countries whose conduct is in contrast with the art. IV of the Statute and, therefore, to formally accuse them of having manipulated the exchange rate.

Secondly, the supervisory function, as repeatedly emphasized during the discussion, qualifies as a soft law tool and, consequently, the Fund's ability to obtain compliance with its mandate, its guidelines, and its recommendations depends on the Members' willingness to implement them and on the degree of cooperation between States Parties in ensuring the effective functioning of the international monetary system. This, in turn, requires, in the presence of an increasingly interdependent international economy, some degree of compromise to reconcile national interests with international ones in the absence of which the Fund's surveillance activity is weakened.

\section{Conclusion}

This study wanted to analyze the main functions of the Fund in the context of the transformations caused by the economic and financial crisis. With regard to supervisory activity, the innovations introduced since 2010 have had the effect of expanding the tools available to the institution to effectively carry out its supervisory function, equipping it with new reports designed to capture the repercussions towards internal and external policies implemented by the various economies and their interactions, allowing the States Parties to have a continuous and detailed flow of information. However, nevertheless, the Fund's action was inadequate in the face of the current global imbalances and the tensions that characterized the currency markets.

Concerning the supervision of stability in the currency markets, the debate within the Fund focused on the alleged adverse effects that UMPs would have produced on emerging countries. The institution has therefore operated in a context where the difficult problem of balancing the needs of countries with different preferences, interests, and questions has been raised. In fact, on the one hand, the emerging countries have accused the advanced economies of having conducted "currency wars", that is to say of having deliberately adopted accommodative monetary measures in an "unconventional" way, not caring about the effects they would have on exchange rates, improperly altering the competitiveness of national productions and damaging that of their commercial partners. On the other hand, advanced countries have claimed to have adopted expansive monetary policies for internal purposes, to reinvigorate national economies, and not to achieve unfair advantages. In light of these considerations, we have assessed whether the write-downs occurring since 2008 can be considered as exchange rate manipulations adopted in order to secure unfair competitive advantages vis-à-vis other states. Using the criteria developed by the economic literature, we carried out a study aimed at identifying which countries out of a total of 184 economies, in the period between 2008 and 2016 manipulated the exchange rate. In particular, our analysis identified fifteen countries (Taiwan, South Korea, Israel, China, Thailand, Macao, Switzerland, Hong Kong, Singapore, Norway, Qatar, United Arab Emirates, Kuwait, Trinidad and Tobago and Saudi Arabia) which during the period considered, they massively intervened in the foreign exchange market, keeping their respective currencies undervalued and acquiring an unfair competitive advantage to the detriment of the partner economies.

Overall, it appears that - in the context of a (not) fragmented, multipolar and multi-currency international monetary system, in which there is a risk that domestic policies undertaken to ensure internal stability will adversely affect other economies, transmitting unstable conditions on the markets - the institution that in the intentions of the founding fathers would have had to perform the function of impartial referee is, instead, to play that of trusted advisor, often unheard, of the Member States. 


\section{References}

Bazerman, M.H., \& Moore, D. (2009). Judgment in Managerial Decision Making (7th ed.). Hoboken, New Jersey: John Wiley and Sons.

Catte, C., \& Pagano, V. (2010). The Role of Macroeconomic Policies in the Global Financial Crisis. Banca d'Italia, Occasional Paper No. 69. https://doi.org/10.2139/ssrn.1721429

Evans, P., \& Finnemore, E. (2011). Organizational Reform and the Expansion of the South'sVoice at the Fund. G-24 Discussion Paper n.15, December 2001.

Independent Evaluation Office. (2006). Multilateral Surveillance. Evaluation Report.

Independent Evaluation Office. (2009). IMF Interactions with Member Countries. Evaluation Report.

Independent Evaluation Office. (2013). The Role of the IMF as Trusted Advisor. Evaluation Report.

Independent Evaluation Office. (2014). Recurring Lessons from a Decade of Evaluation: Lessons for the IMF. Evaluation Report.

Independent Evaluation Office. (2014). The IMF's Lending Toolkit and the Global Financial Crisis. IEO Background Paper, October 8, 2014.

Independent Evaluation Office. (2014a). IMF Response to the Financial Crisis. Evaluation Report, IEO, 2014.

Independent Evaluation Office. (2014b). Revisiting the IEO Evaluations of the IMF's Role in PRSPS and the PRGF (2004) and The IMF and Aid to Sub-Saharan Africa (2007). Evaluation Update, IEO, 2014.

Independent Evaluation Office. (2017), IMF Exchange Policy Advice. Evaluation Update, 2017.

Independent Evaluation Office. (2017). IMF Advice on Unconventional Monetary Policy. Evaluation Report, September 2017.

Independent Evaluation Office. (2017). Multilateral Surveillance: Revisiting the 2006 IEO Evaluation. Evaluation Report.

Indepent Evaluation Office. (2011). Evaluation of IMF Performance in the Run-Up to the Financial and Economic Crisis-Multilateral Surveillance. IEO Evaluation Report, January 10.

International Monetary Fund. (2014). 2014 Triennial Surveillance Review - Managing Director's Action Plan for Strengthening Surveillance, IMF Policy Paper, November.

International Monetary Fund. (2014). 2014 Triennial Surveillance Review - Overview Paper, IMF Policy Paper, July.

International Monetary Fund. (2014). Press Release No 14/368, IMF, 2014. https://doi.org/10.5089/9781498337922.002

International Monetary Fund. (2014). Review of the Flexible Credit Line, the Precautionary and Liquidity Line, and the Rapid Financing Instrument. IMF Policy Paper, January 272014.

International Monetary Fund. (2014). Revised Operational Guidance to IMF Staff on the 2002 Conditionality Guidelines. August 2014.

International Monetary Fund. (2014c). IMF Executive Board Discusses FCL, PLL, and RFI Review. Press Release No. 14/84, March. https://doi.org/10.5089/9781484341698.002

International Monetary Fund. (2015). Guidance Note for Surveillance under Article IV Consultation, May 2015.

International Monetary Fund. (2015). The Flexible Credit Line - Operational Guidance Note. June 1, 2015. https://doi.org/10.5089/9781513537054.002

International Monetary Fund. (2015a). The Precautionary and Liquidity - Operational Guidance Note. June 1, 2015. International Monetary Fund. (2016). Conditionality Factsheet, IMF, April 2016.

International Monetary Fund. (2016). Former Yugoslav Republic of Macedonia, 2016 Art. IV Consultation - Press Release and Staff Report. IMF Country Report No 16/356, November 2016. https://doi.org/10.5089/9781475554816.002

International Monetary Fund. (2016). The IMF's the Flexible Credit Line. IMF Factsheet, March 2016. 
International Monetary Fund. (2017). 2017 Art. IV Consultation - Press Release; People Republic of China. August 2017. https://doi.org/10.5089/9781475589009.002

International Monetary Fund. (2017). 2017 External Sector Report. IMF Policy Paper, July 2017, Washington: International Monetary Fund.

International Monetary Fund. (2017). 2017 Spillover Report. Washington: International Monetary Fund.

International Monetary Fund. (2017a). Colombia - Review under Flexible Credit Line Arrangement, Press Release and Staff Report. June 2017. https://doi.org/10.5089/9781484303320.002

International Monetary Fund. (2017b). Mexico - Review under Flexible Credit Line Arrangement, Press Release and Staff Report. May 2017. https://doi.org/10.5089/9781484301364.002

International Monetary Fund. (2017c). Poland - Review under Flexible Credit Line Arrangement, Press Release and Staff Report. January 2017. https://doi.org/10.5089/9781484303320.002

International Monetary Fund. (2008). Reform of Quota and Voice in the International Monetary Fund, - Draft Report of the Executive Board to the Board of Governors. IMF Policy paper, March 28.

International Monetary Fund. (2008a). Review of the Fund's Financing Role in Member Countries. SM/08/283, (Washington), August.

International Monetary Fund. (2009). Integrating Financial Sector Issues and FSAP Assessments into Surveillance-Progress Report. (Washington D.C.), January 16.

International Monetary Fund. (2009a). Review of Fund Facilities-Analytical Basis for Fund Lending and Reform Options. SM/09/35 (Washington), February.

International Monetary Fund. (2009d). IMF Executive Board's Initial Discussion on Review of Fund Facilities-Analytical Basis for Fund Lending and Reform Options. Public Information Notice (PIN) No. 09/41, April. https://doi.org/10.5089/9781451808957.002

International Monetary Fund. (2009e). IMF Overhauls Nonconcessional Lending Facilities and Conditionality. Public Information Notice (PIN) No. 09/40, April. https://doi.org/10.5089/9781451837957.002

International Monetary Fund. (2010). Financial Sector Surveillance and the Mandate of the Fund. IMF Policy paper, March 19.

International Monetary Fund. (2010). Modernizing the Surveillance Mandate and Modalities. IMF Policy paper, March 26.

International Monetary Fund. (2010). Regional Financial Safety Nets to Create Stronger Links. IMF Survey Magazine: Policy, October 26.

International Monetary Fund. (2010). Reserve Accumulation and International Monetary Stability. IMF Policy paper, April 13.

International Monetary Fund. (2011). 2011 Triennial Surveillance Review - Overview Paper. IMF Policy Paper, August.

International Monetary Fund. (2012a). 2011 Review of Conditionality - Overview Paper. IMF, June 192012.

International Monetary Fund. (2012b). 2011 Review of Conditionality - Background Paper 1: Content and Application of Conditionality. IMF, June 182012.

International Monetary Fund. (2012c). 2011 Review of Conditionality - Background Paper 2: Design of Fund-Supported Programs. IMF, June 182012.

International Monetary Fund. (2012d). 2011 Review of Conditionality - Background Paper 3: Outcomes of Fund-Supported Programs. IMF, June 182012.

International Monetary Fund. (2012e). 2011 Review of Conditionality - Background Paper 4: Technical Appendices. IMF, June 182012.

International Monetary Fund. (2012f). External Balance Assessment (EBA): Technical Background of the Pilot Methodology. Washington: International Monetary Fund.

International Monetary Fund. (2013a). Unconventional Monetary Policy - Recent Experience and Prospects. April 18, 2013, Washington: International Monetary Fund. 
International Monetary Fund. (2013b). Global Impact and Challenges of Unconventional Monetary Policy. Policy Paper, October 7, 2013.

Janis, I.L. (1982). Groupthink: Psychological Studies of Policy Decisions and Fiascoes (2nd ed.). Boston, Massachusetts: Houghton Mifflin.

Marzovilla, O., \& Romagnoli, C. (2016). Il Sistema Monetario Internazionale: Dall'Approccio Egemone a quello Multivalutario. Francoangeli Editore.

Moreno, P. (2013). The Metamorphosis of the IMF (2009-2011). Estudios Economicos n. 78, Banco de Espana.

Reinhart, C., \& Rogoff, K. (2009). This Time Is Different; Eight Centuries of Financial Folly. Princeton, NJ: Princeton University Press. https://doi.org/10.2307/j.ctvcm4gqx

Taylor, J.B. (2007). Housing And Monetary Policy. NBER Working Paper No. 13682. Retrieved from http://www.nber.org/papers/w13682

Taylor, J.B. (2009). The Financial Crisis and the Policy Responses: An Empirical Analysis of What Went Wrong. NBER Working Paper No. 14631. https://doi.org/10.3386/w14631 